\title{
The Power of the Supreme Court in the Age of the Positive State: A Preliminary Excursus Part Two: On the Need for Adaptation to Changing Reality
}

\author{
Alan Scheflin \\ Santa Clara University School of Law, ascheflin@scu.edu \\ Arthur Selwyn Miller
}

Follow this and additional works at: http://digitalcommons.law.scu.edu/facpubs

Part of the Law Commons

\section{Automated Citation}

Alan Scheflin and Arthur Selwyn Miller, The Power of the Supreme Court in the Age of the Positive State: A Preliminary Excursus Part Two: On the Need for Adaptation to Changing Reality , 1967 Duke L.J. 522 (1967),

Available at: http://digitalcommons.law.scu.edu/facpubs/683 


\title{
THE POWER OF THE SUPREME COURT IN THE AGE OF THE POSITIVE STATE: A PRELIMINARY EXCURSUS-
}

\section{Part Two: On the Need for Adaptation to Changing Reality}

\author{
ARThUR SELWYN MiLleR* \\ Alan W. Scheflin†
}

Government is not a machine, but a living thing. It falls, not under the theory of the universe, but under the theory of organic life. It is accountable to Darwin, not to Newton. It is modified by its environment, necessitated by its tasks, shaped to its functions by the sheer pressure of life. ... Living political constitutions must be Darwinian in structure and practice. -Woodrow Wilson $\ddagger$

\section{INTRODUCTION}

TN Part One of this article, ${ }^{1}$ three hypotheses which, of necessity, were unsupported by empirical foundation, ${ }^{2}$ were tentatively advanced in an attempt to suggest some ways of thinking about the institutional position of the United States Supreme Court. ${ }^{3}$ It was noted that $a$ priori assertions about the Court and its power are wholly inadequate and that scholarship must go beyond the confines of judicial opinions if a full understanding of America's peculiar

*A.B. 1938, Willamette University; LL.B. 1949, Stanford Law School; J.S.D. 1959, Yale Law School. Professor of Law, The George Washington University.

†B.A. 1963, University of Virginia; LL.B. 1966, The George Washington University Law School; LL.M. 1967, Harvard Law School; Associate Professor of Law, Georgetown Law Center.

¥ Wilson, Constitutional Government in the United States $56-57$ (1908).

${ }_{1}$ Miller \& Scheflin, The Power of the Supreme Court in the Age of the Positive State: A Preliminary Excursus (pt. 1), 1967 DukE L.J. 273.

'A modest survey of students of the Supreme Court revealed that no studies developing the necessary empirical data were known to exist. See id. at 301-20 (Appendix).

The hypotheses are as follows: (1) The prestige of the Supreme Court has little or nothing to do with its symbolic role, but rather with what it does (id. at 281-83); (2) The Supreme Court has power to the extent that it articulates deep-set values (preferences) of the American people (id. at 283.88); and (3) The Supreme Court has power to the extent to which the avowedly political branches of government affirmatively respond to the norm announced hy the Court (id. at 288-94). 
contribution to the science of government is to be developed. In short, a sociology of constitutional adjudication is needed.

In this part of the article, attention is directed to three propositions concerning the need for the Supreme Court to adapt itself to the exigencies of changing reality if it is to retain (or regain) whatever power it has (or may have had). While these propositions are not intended to follow from the prior hypotheses as a matter of inexorable logic, they are related to and are not inconsistent with what has been said before. Taken together, with the reminder that much more factual data is required, they indicate the need for adaptation to the demands brought on by a rapidly changing society.4 The propositions hereinafter discussed include the following: (1) Outward or ostensible adherence to the declaratory theory of law is not necessary for the integrity and continuing viability of the constitutional adjudicatory process; (2) The adversary system is not adequate to the needs of the Court; and (3) The Court in the years ahead must direct itself to the problems of a changing social milieu.

\section{A First Proposition}

The first proposition may be stated as follows: Adherence to the declaratory theory of law is probably not necessary for the integrity and viability of the constitutional adjudicatory process. We say "probably" because we know of no hard "evidence" to validate or invalidate the statement. However, the assertion seems to be a fair conclusion deducible from the flow of Supreme Court decisions in recent decades and bolstered by the observation that at those times when the Court has ostensibly adhered to the declaratory theory (for example, during the early years of the New Deal) its position has been threatened. ${ }^{5}$ Moreover, if as Professors Mishkin and Morris maintain in On Law in Courts, ${ }^{6}$ the declaratory theory is dead, some

- Change is built into the American social structure. Compare LAPP, THE NEW Priesthood: The Scientific Elite and THE Use of Power (1965), with PRICE, The ScIENTIFIC Estate (1965), 1966 Duke L.J. 622. See Miller, Notes on the Concept of the "Living" Constitution, 31 GEO. WASH. L. REv. 881 (1963), and Miller, Technology, Social Change, and the Constitution, 33 GEO. WAsH. L. REV. 17 (1964), for discussions of the factor of change as it relates to the Constitution.

See, e.g., United States v. Butler, 297 U.S. 1 (1936). Butler and similar cases invalidating New Deal legislation led to the Court packing plan of 1937.

- Mishinin \& Morris, ON LAw IN Courts 57 (1965). The roots of the declaratory theory can be traced back to Flaundres and Wife v. Rycheman, Y. B. Hill. 18 \& 19 Edw. 3, pl. 3 (1344-45), in Pike, Year Books of the ReIGN of King Edward III, Years 18 ANo 19, at 374,378 (1905), in which a lawyer argued " $I$ think you will do as others 
additional support for the above proposition is available. As Professor Wolfgang Friedmann has asserted, "The Blackstonian doctrine of the 'declaratory' function of the courts, holding that the duty of the court is not to "pronounce a new law but to maintain and expound the old one,' has long been little more than a ghost." The decline of the declaratory theory permits attention to be diverted "from the stale controversy over whether judges make law to the much more complex and controversial question of the limits of judicial lawmaking."8

Nevertheless, it is evident that the declaratory theory continues to obscure legal scholarship by providing the standard by which judicial decisions are often evaluated. The reasoning of judges, which has long fascinated lawyers and students of the judiciary, has been the subject of numberless written comments. Most of what is printed in legal periodicals today, for example, may be said to consist of efforts to analyze the manner in which judges reach decisions. Very often, the net conclusion of such writings is that the judge reached the correct result but for the wrong reasons. ${ }^{2}$ The author then proceeds to set forth what seem to him to be better reasons. This is exegesis upon judicial texts, casuistry about what judges say are their reasons for decisions. Lawyers, particularly law professors who follow the Supreme Court, seize upon the newly issued opinions of that tribunal and then, in heavily footnoted scholarly disputations, gnaw over what the Justices say. The commentators are apparently more interested in the method than the result. Not so the layman, who either for reasons of indifference or because of innate canniness apparently ignores the opinions and looks to the results.

Similarly, the usual law school casebook or textbook makes little or no reference to the "policy" aspects of legal decisions or the lawmaking proclivities of judges. Witness also the activities of the American Law Institute which purports to "restate" legal doctrine in a series of black-letter propositions, presumably to aid judges in

have done in the same case, or else we do not know what the law is." Judge Hillary 2nswered, "It is the will of the Justice" but Chief Justice Stonore broke in and said, "No; law is that which is right." See also Linkletter v. Walker, 381 U.S. 618, 623 n.7 (1965).

. 'Friedmann, Limits of Judicial Lawmaking and Prospective Overruling, 29 MODERN L. REv. 593 (1966).

Id. at 595 .

- Illustrations are legion. For a recent example, see Horowitz \& Karst, The Proposition Fourteen Cases: Justice in Search of a Justification, 14 U.C.L.A.L. REv. 37 (1966). 
finding and declaring the law a là Blackstone. While it is, as Professor Friedmann asserts, ${ }^{10}$ an exercise in sterility to debate the question of judicial creativity, an explanation of the operation and basis of the declaratory theory is necessary to round out the development of this article.

According to Blackstone, the judge is "sworn to determine, not according to his own private judgment, but according to the known laws and customs of the land; not delegated to pronounce a new law, but to maintain and expound the old one."11 Only in this way, according to the theory, can the litigants, and society at large, be assured that the same acts will be treated the same way and that, in essence, reliance may be placed on law. ${ }^{12}$ If law is to be a guiding principle in society and the matrix within which the affairs of men may be legitimately conducted, it must be obeyed, and "to be obeyed or followed, must be known; to be known it must be fixed; to be fixed, what is decided today must be followed tomorrow."13 The declaratory theory posits the principle of stare decisis as the only effective means for maintaining stability in the legal system, protecting reliance, and checking judicial caprice by restricting the limits within which the judge may operate.

The declaratory theory also is said to serve another useful function. Professor Mishkin has stated that, as a symbolic expression of the judicial process, it accounts in large measure for the prestige of the courts. There is, he asserts, a "strongly held and deeply felt belief that judges are bound by a body of fixed, overriding law, that they apply that law impersonally as well as impartially, that they exercise no individual choice and have no program of their own to. advance."14 However, whatever role the symbolic conception plays

\footnotetext{
${ }^{10}$ Friedmann, supra note 7 , at 595 .

21 Blackstone. Commentaries -69. Compare Bacon, Of Judicature: "Judges ought to remember, that their office is jus dicere, and not jus dare; to interpret law, and not to make law, or give law. Else will it be like the authority, claimed by the Church of Rome, which under pretext of exposition of Scripture, doth not stick to add or alter; and to pronounce that which they do not find; and by show of antiquity, to introduce novelty."

${ }^{22}$ This position appears to be the main thrust of Professor Lon Fullers' eight principles of legality. See FuLler, THE Morality OF LAW 33-39 (1964).

${ }^{18}$ Kaufman, $A$ Defense of Stare Decisis, 10 Hastings L.J. 283, 284 (1959).

14 Mishkin, The High Court, The Great Writ, and the Due Process of Time and Law, 79 HARv. L, Rev. 56, 62 (1965). For another criticism of Professor Mishkin's article, see Schwartz, Retroactivity, Reliability, and Due Process: $A$ Reply to Professor Mishkin, 33 U. CHr. L. REv. 719 (1966).
}

Thurman Arnold maintains that "the ideal of a government of laws rather than 
in the relationship between the public and the law as announced in courts, surely there is a negative side to it. Even if it could be demonstrated that the symbol is valuable, it obviously conceals truth. Merely by being a symbol, it necessarily obscures the real foundation of what is symbolized. Nevertheless, Professor Mishkin maintains that if the declaratory theory "be in part myth, it is a myth by which we live and which can be sacrificed only at substantial cost." 15 While acknowledging that the truth behind the symbol ought not be obscured to anyone wishing to learn and taking the trouble to understand, he goes on to say:

At the same time, 'I see no affirmative virtue in the destruction of essentially sound and valuable symbols in order to promulgate a part of a more sophisticated-and indeed over-all more accurategeneral view. Such partial truths do not necessarily represent a gain in wisdom over the more elementary general view, and the destruction of the symbol does involve real loss. Though I know that judges are human and quite distinct individuals, I am not in favor of their doffing their robes, for I think there is value in stressing, for themselves and for others, the quite real striving for an impartiality I know can never be fully achieved. ${ }^{16}$

The trouble with this position is multiple. First, it assumes that truth about the judiciary (whatever it may be) can be kept from the people at large. As education spreads and as the mass media reach into every home, that assumption is dubious at best. Second, where does an elite, however defined, acquire its warrant or license to keep the truth from others?" Third, it is difficult to grasp what "real

men is a necessary one. Briefs could not be written before a court on any other premise. This very simple ideal is essential to the public acceptance of our judicial system and to all steps in the judicial process." Letter from Thurman Arnold to Arthur S. Miller, March 23, 1966 (quoted with permission). However, briefs could not be written before an appellate court on any other premise than that the law is sufficiently uncertain to permit opposing arguments. See Miller, On the Choice of Major Premises in Supreme Court Opinions, 14 J. PuB. L. 251 (1965).

15 Mishkin, supra note 14.

18 Id. at $63 \mathrm{n} .29$.

${ }^{17}$ For, "in the long run ... any government institution must rest upon a full understanding of its function and operations by the public; . . . concealment, deception or ignorance weakens and eventually will destroy an institution." Letter From Professor Thomas Emerson of the Yale Law School to Arthur S. Miller, May 12, 1966 (used by permission).

An unexplored area of constitutional concern is the meaning for the first amendment's freedoms of expression, as well as the meaning for democratic government generally, of a government which "manages" news, pursues secrecy policies, at times is not candid, and otherwise pollutes the stream of information to the people. The 
loss" would occur if the truth were known about the judicial process. To call it a loss is to fall into the Holmesian fallacy of looking at the law solely through the eyes of the "bad man." 18 Law, if it means anything, must mean more than the workings of the judicial process. ${ }^{19}$ One must visualize the social role of law in the myriad of day-to-day transactions of people, rather than in those disputes which are sent to lawyers or which end in judicial decision. ${ }^{20}$ Fourth, to our knowledge no one has suggested that judges doff their robes. Candor does not require that pomp and ceremony be eliminated or that the awesome dignity of the Court be discarded. We cheerfully concede that there is some value in the outward trappings of courts. ${ }^{21}$ Fifth, again we know of no one who has ever suggested or implied that judges should not strive for "impartiality." But is that effort to achieve what Frankfurter called "an invincible disinterestedness"22 to be attained by adherence to the declaratory theory? We think not. Moreover, the connection which impartiality has with the alleged need for adhering to the declaratory theory is not selfevident. ${ }^{23}$ Sixth, the perpetuation of error at the expense of truth is dangerous because the error may be forgotten as error and believed

"market place" theory of truth becomes at least shaky, if not repudiated. See, e.g., Dennis v. United States, 341 U.S. 494, 503-05 (1952); Abrams v. United States, 250 U.S. 616, 630-31 (1919) (Holmes, J., dissenting).

${ }^{18}$ Holmes, The Path of the Law, 10 Harv, L. REv. 457, 459 (1897).

${ }^{10}$ See Hart, The Concept of LAw passim (1961), for an exposition of the "good man" theory.

${ }^{20}$ See Miller, $A$ Note on the Criticism of Supreme Court Opinions, 10 J. PuB. L. 139 (1961).

${ }^{21}$ It is not at all clear why the Supreme Court enjoys prestige as a result of the rituals or myths which surround it. The prestige may derive from the mystery of the Tribunal. Cf. Reston, The Mysterious Ways of Lyndon Johnson, N.Y. Times, Aug. 21, 1964, p. 28, col. 3 (quoting President Charles de Gaulle): “There can be no prestige without mystery. ... In the designs, the demeanor, and the mental operations of a leader, there must always be a 'something' which others cannot altogether fathom, which puzzles them, stirs them, and rivets their attention."

The Court may also satisfy the psychological needs of persons. See Frank, Law AND THE MODERN MIND 243-52 (1931).

${ }^{22}$ Frankfurter, John Marshall and the Judicial Function, in GOVERNMENT UNDER LAw 6, 21 (Sutherland ed. 1956).

${ }^{23}$ Frankfurter seemed to say as much in his well-known majority opinion in Rochin v. California, 342 U.S. I65 (1952): "We may not draw on our merely personal and private notions and disregard the limits that bind judges in their judicial function." Id. at 170. "To practice the requisite detachment and to achieve sufficient objectivity no doubt demands of judges the habit of self-discipline and self-criticism, incertitude that one's own views are incontestable and alert tolerance toward views not shared." Id. at 171. "[T] $]$ hese are precisely the presuppositions of our judicial process. They are precisely the qualities society has a right to expect from those entrusted with ultimate judicial power." Id. at 172. 
as truth; fictions have a way of becoming pernicious. Deliberate obfuscation will ultimately destroy; planned obscurantism by an intellectual elite cannot be justified. Finally, it may well be that the truth, however much it is hidden, will out, sooner or later; and it is better for the revelation to occur sooner so that conscious efforts to deal with it'may be undertaken.

The declaratory theory rests upon at least two erroneous premises. The first and most obvious fallacy is the assumption that the law is not a creation of men but rather exists as some form of Platonic Idea. ${ }^{24}$ The second, and perhaps more crucial, error upon which the theory is based is the assumption that the judicial process operates at an ideal level. This premise, however, is simply not true. ${ }^{25}$

In addition to resting upon two erroneous premises, the declaratory theory is also subject to attack upon another ground. There exists today the very real and very perplexing problem of the proliferation of precedents. ${ }^{28}$ The geometric progression of reported cases, estimated at over 100,000 pages of reported judgments or 70 million words per year issuing from state courts of last resort and federal courts, ${ }^{27}$ has the effect of making it possible to find case support for almost any theory or argument. Stare decisis loses meaning when alternate lines of authority exist in opposition to each other; the force of a guiding criterion is no longer available. ${ }^{28}$ It is only when one line of authority exists, which is seldom in fact true, that stare decisis is operative because only then does it provide a criterion for decision. ${ }^{29}$ What is really at stake is the nature of the adversary system itself. But in a more limited fashion, the prolifera-

"See Cooperrider, The Rule of Law and the Judicial Process, 59 Mich. L. REv. 501, 507 (1961).

${ }^{28}$ See Breitel, Ethical Problems in the Performance of the Judicial Function, in CONFERENCE ON JUDICLAL ETHICs 64,67-68 (University of Chicago Conference Series No. 19, 1965): "[The adversary system] . . . with the altogether proper commitment of the lawyer to his client and his client's cause, all but absolute, is not exactly akin to the asceptic techniques of the laboratory .... The popular notion that judges are mere declarers of what is in the books, all laid down clearly and simply, is not confined to the laity. It obtains too with large segments of the bar. And judges still believe it."

so See Gilmore, Legal Realism: Its Cause and Cure, 70 YALE L.J. 1037, 1041 (1961).

27 STONE, Legal SYSTEM AND LAWXers' ReAsonings 13 (1964).

${ }^{28}$ This phenomenon has been called the "principle of doctrinal polarity." Miller, $A$ Note on the Criticism of Supreme Court Opinions, 10 J. PuB. L. 139, 144 (1961). With several lines of authority the doctrine becomes multipolar.

${ }^{20} \mathrm{It}$ is the choice between conflicting doctrinal principles that makes any decision creative. See Schaefer, Precedent and Policy, 34 U. CHI. L. REv. 3, 4 (1966). 
tion of precedents weakens the declaratory theory by making the doctrine of stare decisis, which is its backbone, impracticable.

With such serious defects, it might be wondered how the declaratory theory has attained acceptance, both within the profession and with certain segments of the laity. Part of the reason is that it neatly fits into the mainstream of western thought epitomized in Newtonian mechanics and Cartesian philosophy. The declaratory theory has an illusion of certainty, a mechanical appeal that is almost mathematical. The classic treatment of legal reasoning bears out this thesis. It is commonly believed that legal thinking is a deductive-analogistic process in which prior cases are related by analogy to the case at hand and conclusions deduced therefrom. ${ }^{30}$ But if this is true, what does the lawyer argue when the precedents are clearly against him? How does he argue policy? How does he present statistics to the court? Indeed, it is at this point that one may rightfully ask: "How can courts, supposedly by logical deduction from non-contemporaneous legal propositions, and without entering upon social and ethical inquiries, reach conclusions so well adapted (on the whole) to contemporary problems?"31 Julius Stone finds the answer by a thorough examination of what he calls "the categories of illusory reference" which, in the process of legal reasoning, "serve as devices permitting a secret and even unconscious exercise by courts of what in the ultimate analysis is a creative choice." 32 By thus attacking the logical form of the traditional doctrine of legal reasoning, Stone manages to show that there cannot be, in effect, strict deductive reasoning in law. This circumstance forces the judge to base his decision on other considerations, such as public policy and statistical facts, though he may not want to do this. ${ }^{33}$ It is this inherent problem in the judicial process that may in large

${ }^{80}$ Dean Levi categorizes legal reasoning as a three-step process "described by the doctrine of precedent in which a proposition descriptive of the first case is made into a rule of law and then applied to a next similar situation. The steps are these: similarity is seen between cases; next the rule of law inherent in the first case is announced; then the rule of law is made applicable to the second case." LEvr, AN INTRODUCTION TO LEGAL REASONING 2 (1949). Reasoning, thus, is by example or analogy. See generally Schaefer, supra note 29.

sI STONE, op. cit. supra note 27 , at 240.

32 Id. at 241 .

s' As Holmes pointed out, "perhaps one of the reasons why judges do not like to discuss questions of policy, or to put a decision in terms upon their views as lawmakers, is that the moment you leave the path of merely logical deduction you lose the illusion of certainty which makes legal reasoning seem like mathematics." Holmes, Privilege, Malice, and Intent, 8 HARV. L. REv. 1, 7 (1894). 
measure be responsible for the continued acceptance of the declaratory theory.

A better explanation of the nature of legal reasoning has been offered by philosopher John Wisdom. Directing himself to the case where there are no issues of fact in dispute, he observes that

in such cases we notice that the process of argument is not a chain of demonstrative reasoning. It is a presenting and representing of those features of the case which severally co-operate in favour of the conclusion, in favour of saying what the reasoner wishes said, in favour of calling the situation by the name by which he wishes to call it. The reasons are like the legs of a chair, not the links of a chain. Consequently although the discussion is a priori and the steps are not a matter of experience, the procedure resembles scientific argument in that the reasoning is not vertically extensive but horizontally extensive-it is a matter of the cumulative effect of several independent premises, not of the repeated transformation of one or two. ${ }^{34}$

Wisdom's analysis is helpful to explain the weight of the many factors involved in a decision, and his metaphor of the "legs of a chair" provides a scheme for graphically demonstrating the force of each competing interest in a legal problem or litigation. The prevalent notion of the process of legal reasoning is only a halftruth; it represents only one of the "legs of a chair." Thus, one leg is reliance upon rules of law, another is the possible unsettling effect of new rules of law, a third is the precedents, a fourth is the policy arguments, and so forth. The point is that the nature of legal reasoning, while giving the appearance of being mathematical and syllogistic, is more intricate and less certain than is normally conceived. In addition, it is sui generis. Reasoning in law, just as reasoning in morals, suffers from a comparison to, or equation with, either deductive or inductive logic..35 The myth of mechanistic (declaratory) reasoning clouds a clearer picture of the actual process. A discarding of this myth would prompt the bench and the bar openly to concede and thus more effectively to realize that there are other, and more important, matters to argue before a court than the precedents; and at least there should be several matters argued

. Wisdom, Gods, in Proceednges of the Aristotelian SocietY 185, 194 (1945), re. printed in FLEW, LOGIC AND LANGUAGE 194, 203 (1965).

${ }^{35}$ See Hare, The language of Morals (1952); Toulmin, Reason in Ethics 67.85 (1950). See generally Gottlieb, The Logic of Choice: An Inquiry into the Logic of Judicial Argument, 1961 (unpublished thesis in Harvard Law School Library). 
and not merely the precedents. Furthermore, the flow of information to a court, as well as its institutional makeup, might be recognized to be in need of re-examination and change.

The cogency of the declaratory theory also rests upon misconstruction of its antithesis. Why should judges be limited in their function to merely "finding" a pre-existing law? What danger is there in allowing a judge to "create" law? ${ }^{36}$ The declaratory theory rests in part upon a reductio ad absurdum argument which runs as follows: if we allow judges to do more than find the law, we shall be inviting judicial caprice with the result that similar cases will not be decided similarly; the symmetry of the law will be destroyed; personal feelings of the judge rather than law will govern; reliance upon law will become an impossibility. In other words, the only alternative to the declaratory theory is no acceptable system at all, so the theory must be correct, or at least the only one feasible. This conclusion, however, is a non sequitur. The alternative to the declaratory theory is not necessarily judicial caprice but rather a restricted from of recognized judicial creativity. To assert that the role of the judge is broader than merely finding the law is not to say that the judge will be entirely free to follow his own predilections. The fallacy involved here is the "all-or-nothing mistake" which assumes "a naked dichotomy where no such simplification is warranted." 37

Once it is recognized that the rejection of the declaratory theory does not mean the adoption of judicial caprice, a weighty argument for retention of the theory is dissipated. That theory, by postulating a straw enemy, became the answer to what appeared to be a very serious problem: if one did not accept the theory, judges would be uncontrolled and uncontrollable. The only solution was to prevent the subjective element from entering into the decisional process, either in the form of personal bias or innovative ability. This position, carried to its necessary conclusion, would require removing judges and replacing them with logicians since the really important

${ }^{30}$ Before the rise of legislatures and codification, which came in the nineteenth century, most law was created by judges. See Wyzanski, History and Law, $26 \mathrm{U}$. CHr. L. REv. 237, 240-42 (1959). In recent years, the notion has spread that only legislatures can "make" law, but the notion is false. Not only courts, but executives and administrators, make law-and at an increasing rate. Even private organizations participate directly in the law making process. Compare Truman, The Governmental Process (1951) with MCConNeli, Private Power and AMERICAN Democracy (1966).

3i See Fearnside \& Holther, Faliacy-The Counterfeit of Argument 30 (1959). 
element is the deductive syllogism from the precedents to the instant case. $^{38}$ That there is a subjective element in judicial decisionmaking, and a large one at that, can no longer be doubted. ${ }^{39}$ And the unavoidable subjective element in law, coupled with a referential element linking law with society in general, demands a more sophisticated view of the judicial process than the declaratory theory is capable of supplying.

It may be objected that although the alternative to the declaratory theory is not necessarily judicial caprice, nevertheless the door to caprice is opened by removal of the only fetters upon the judges that the legal system imposes. In other words, the declaratory theory may not be completely accurate, but at least it offers a restraint upon judges that is otherwise unavailable. Thus, according to a nineteenth century judge, "Nothing keeps a judge so strictly in the line of his duty, as the feeling and constant realization of the fact, that he is bound by precedents. He knows, that his opinion will be by the legal profession with all its astuteness subjected to the severest criticism, and if he dares to depart on a given question from the well marked line of precedents, either his ability or integrity is in great danger of being impugned." 40 The answer to this assertion is that there are institutional restraints upon the office; the judge is not to act from individual and personal motives but rather he should decide the case according to "law" which may or may not be represented in precedents. It is not a "government of men" to decide outside the doctrine of precedent if it is recognized that "law" means more than precedent and if the case is decided disinterestedly. In an age of legislative and even more of executive dominance, it seems a bit odd to be concerned about "judicial tyranny." The real problem is how to make courts more effective.

Some may object that this discussion is moot since nobody believes in a strict version of the declaratory theory. ${ }^{41}$ While few per-

${ }^{88}$ See Breitel, supra note 23, at 69: "The key numbers in the digests will give you the cases, the black letter in the hornbooks and the Restatements will give you the principles, let the lawyers do the work, and just carry along placidly until the day comes when the computers will make it even easier."

s' See Miller \& Howell, The Myth of Neutrality in Constitutional Adjudication, 27 U. CHI. L. REv. 661, 671-83 (1960); Yntema, The Hormbook Method and the Conflict of Laws, 37 YALE L.J. 468, 477 (1928).

${ }^{10}$ Clarke \&: Co. v. Figgins, 27 W. Va. 663, 672 (1886).

1 But see STONE, op. cit. supra note 25, at 235. The history of the strict English deference to stare decisis is traced in HART \& SAcks, ThE LEgal Process: Basic Phos. 
sons accept the theory in full force, such an objection misconceives the effect of overt removal of the theory, the advantages of which are varied. In the first place, removal would give a clearer picture of how the system operates and thereby make it easier to identify its deficiencies. In addition, arguing a case before a judge would be more purposeful, for the judge and the lawyers would be forced to see "all" of the legs of the chair, not just some of them. In each case the movement of law could be seen as only a part of the larger movement of society. Moreover, the strained contortions through which some courts now go to fit a decision into a well-developed line of authorities could be avoided. ${ }^{42}$ More importantly, however, the removal of the vestiges of the declaratory theory would provide a foundation for a different view of the role of the judicial process. Although these advantages are somewhat less significant with regard to the Supreme Court, which has tended to be a policy maker on a grander scale than other courts, nevertheless, it is important to see that the judicial process, vis-à-vis the other governmental processes of law making, is basically creative.

However, Professor Mishkin has suggested that public disaffection

Lems in the Making and Application of Law 592-95 (Tent. ed. 1958). Recently, however, the House of Lords announced that it will no longer consider-itself strictly bound by precedents. See [1966] I Weekly L.R. 1234: "Their Lordships regard the use of precedent as an indispensable foundation upon which to decide what is the law and its application to individual cases. It provides at least some degree of certainty upon which individuals can rely in the conduct of their affairs, as well as a basis for orderly development of legal rules.

"Their Lordships nevertheless recognize that too rigid adherence to precedent may lead to injustice in a particular case and also unduly restrict the proper development of the law. They propose, therefore to modify their present practice and, while treating former decisions of this House as normally binding, to depart from a previous decision when it appears right to do so.

"In this connection they will bear in mind the danger of disturbing retrospectively the basis on which contracts settlements of property, and fiscal arrangements have been entered into and also the especial need for certainty as to the criminal law."

See Leach, Revisionism in the House of Lords: The Bastion of Rigid Stare Decisis Falls, 80 HARv. L. REv. 797 (1967). See also Llewellyn, On Warranty of Quality, and Society, 36 ColuM. L. REv, 699, 737 (1936): "Still, in the main, secret judicial innovation lends itself lightly to rape which may be unintentional. It is better policy, though worse manners, for judges to say so, when they change the law. Change it, to my mind, and by my reading of the books, they not only do, and must, but should. . . . Still they should see and say what they are doing."

${ }^{12}$ We believe, with Professor Corbin, that "a better hrand of justice may be delivered by a court that is clearly conscious of its own processes, than by one that states hard-bitten traditional rules and doctrines and then attains an instinctively felt justice by an avoidance of them that is only half-conscious, accompanied by an extended exegisis worthy of a medieval theologian." 3 Corbin, Contracts $\$ 561$, at 279 (rev. ed. 1960). 
would accompany public realization that the United States Supreme Court makes policy. ${ }^{43}$ As Professor R. G. McCloskey has pointed out, and as our modest survey buttresses, the prestige of the Court appears to rest upon factors unrelated to the declaratory theory. ${ }^{44}$ The mystique of the Court and the extent to which people agree with the conclusions of Court decisions seem to be far more important to the Court's prestige. ${ }^{45}$ In fact, abandonment of the declaratory theory would enable the Court to articulate more closely the reasons for its decisions and thus provide clearer guides for the people to follow. ${ }^{48}$ Perry Miller has pointed out that at the turn of the nineteenth century there was great antagonism towards the law because it was too sophisticated for the common man who was unable to use it as a guide for his conduct. ${ }^{47}$ With the increased press coverage of the Supreme Court and even lesser tribunals, the public is becoming increasingly aware of the nature and functioning of the judicial process. Furthermore, public interest has increased as the type of cases with which the Court deals vitally affect every person. The apportionment cases, the vast area of civil rights and civil liberties, voting rights, and even obscenity, are pervasive enough to draw into their net the concern of the entire community. Using Alexander Pekelis's phrase, the Court has indeed become immersed in the "travail of society," 48 which means that much more will be demanded of law because the public appears to be expecting much more.

\footnotetext{
13 Mishkin, supra note 13, at 67-70.

"Mccloskey, Principles, Powers and Values: The Establishment Clause and the Supreme Court, in ReIJGION AND THE PUBLIC ORDER 3, 29 n.60 (Giannella ed. 1965): "The trouble is that, although we are accustomed to talk loosely about the 'prestige' of the Court, we know very little about its nature or about what causes it to ebb and flow. I would suggest that when we use the term, we usually have two somewhat different things in mind: The pro-judicial opinion that derives from approval of the Court's specific recent policy trends, and the pro-judicial opinion that rests on a belief in the value of the judicial institution, quite apart from the question of how that institution is currently behaving. Obviously the first variety is less constant and dependable than tbe second, and it would be useful (though perhaps impossible) for purposes of prediction to know what proportion of the Court's 'prestige' at any given time is to be attributed to each."

'S See Miller, Some Pervasive Myths About the United States Supreme Court, 10 ST. Lours U.L.J. 153, 154-56 (1965).

to "In a good society bad laws are never happily tolerated, but uncertain law is intolerable." Wall Street Journal, June 23, 1966, p. 14, col. 1.

17 MILleR, The Life OF THE Mind in AMertaA 102-04 (1965).

48 PekeIIs, The Case for a Jurisprudence of Welfare, in LAw ANd SOcLAL Action 1, 40 (Konvitz ed. 1950).
} 
The core of the problem created by the declaratory theory is reconciling legal change with the notion of certainty. Simply because society is in a period of extremely rapid change, the law cannot stand still; law by and large must reflect the society in which it exists and which it seeks to govern. ${ }^{49}$ With change both constant and cataclysmic, there should be little wonder that law moves both legislatively and judicially. The Constitution must, of course, be updated; the responsibility for this function rests largely, although not entirely, with the United States Supreme Court.50 In its decisions, the Court necessarily must be forward-looking, purposive, teleological, immersed in the travail of society. Otherwise it could scarcely serve its constitutional purpose. This does not sit well with those who yearn for an elegantia juris, for a Court that operates in accordance with their own preconcevied notions of propriety. ${ }^{52}$

In the final analysis, what is wanted from the Supreme Court are

${ }^{60}$ As Professor M. S. McDougal points out, we are not concerned with a "mere body of rules but with a whole process of decision, and a process of decision making taking place within the context of, and as a response to, a larger community process." McDougal, Law as a Process of Decision: A Policy-Oriented Approach to Legal Study, 1 NATURAL L.F. 53, 56 (1956).

${ }^{\circ 0}$ The Constitution may be "changed" by any of our instruments of governance. For example, the internal alterations made by the executive and legislative branches work a change in the constitutional order. Similarly, the failure of state governments to assume their responsibilities has contributed heavily to the decline of federalism. In addition, the Constitution can be altered by amendment. Furthermore, long continued usage, as in the rise of political parties, may be said to effect constitutional change.

${ }^{81}$ Those who would restrict the courts to performing exclusively logicians' exercises fail to realize that political theories explain the function of government rather than dictate it. Some statements of Nobel Prize winner in physics, Percy W. Bridgman, seem apposite: "I will not attach as much importance as do apparently a geod many professional lawyers to getting all law formulated into a verbally consistent edifice. No one who has been through the experience of modern physics ... can believe that there can be such an edifice, but it seems to me that nevertheless I can sometimes detect an almost metaphysical belief in the minds of some people in the possibility of such an edifice. If one needs specific details to fortify his conviction that there is no such edifice, plenty can be found. ... The situation ... for the lawyer resembles somewhat the general situation for the scientist. We have seen that in the popular view the scientist assumes that nature operates according to certain broad sweeping generalities. This is paraphrased by saying that the scientist must have 'faith' that there are natural laws. We have not accepted this view. It seems to me that a better description of how the scientist operates is to say that he adopts the program of finding as much regularity as he can in the operation of nature, without any prior commitment as to how much he will find. So too it seems to me that here the lawyer should and can make no prior commitment about the possibility of erecting a self-contained self-consistent verbal legal edifice, but all that he can strive for is as self-contained and logically consistent an edifice as he can erect." BRDGMAN, The WAY ThINGS ARE 308.09 (1959). (Emphasis in original.) 
wise decisions, wise in the sense of furthering the values of a democratic polity. If with such decisions there may also be obtained opinions which fit within the concept of idealized versions of the judiciary, so much the better. But the Court has never operated in that manner; it has always been content to make its decisions and to "explain" them in opinions most of which any first-year law student can pull apart with ease. The Justices have always been "result oriented" and politically minded. They have been cognizant of the political consequences of their decisions. In their appraisal of these consequences, they have sometimes erred, as in Dred Scott, ${ }^{62}$ Pollack, ${ }^{53}$ and Butler. ${ }^{54}$ More often, they have overruled themselves. ${ }^{55}$ Often, perhaps routinely, they have innovated, ${ }^{56}$ in the sense that any ruling on the merits has an element of creativity. In any event, the Court in recent years has had to attempt to adapt itself to changing reality, and it is that effort that is the subject of our concern.

\section{A Second Proposition}

It seems evident that an effort is being made by the Court, silently and with indifferent success thus far, to develop new institutional means of dealing with the questions of public policy which are presented to it. These questions may involve statutory interpretation or constitutional construction. As Tocqueville and others have observed, all questions of public policy do not reach the Court; nevertheless, they appear there with sufficient frequency to make the Court an important organ of American governance. A second proposition, then, may be stated thusly: The adversary system, as it has developed, is not entirely suitable to the resolution of the important problems of public polciy which the Court is forced to decide. It seems accurate to assert that the Justices have already recognized the

\footnotetext{
52 Dred Scott v. Sandford, 60 U.S. (19 How.) 393 (1857) (invalidating Missouri Compromise of 1820$)$.

sa Pollack v. Farmers' Loan \& Trust Co., 157 U.S. 429 (1895) (invalidating federal income tax).

sk United States v. Butler, 297 U.S. 1 (1936) (invalidating Agricultural Adjustment Act of 1933).

${ }^{55}$ See generally Blaustein \& Field, "Overruling" Opinions in The Supreme Court, 57 Mich. L. Rev. 151 (1958); Ulmer, An Empirical Analysis of Selected Aspects of Lawmaking of the United States Supreme Court, 8 J. PUB. L. 414 (1959).

"6o The "prospective" overruling cases appear to represent an innovation which rests heavily upon political and practical "consequence orientation." This device has allowed the Court to change the law without throwing open all the jails of the country. See, e.g., Johnson v. New Jersey, 384 U.S. 719, 726-35 (1966).
} 
validity of this proposition. The recognition that "policy" plays as great a part as doctrine in the decisional process, the growing tendency to use "non-legal" materials to buttress decisions, the widespread employment of the most open and liberal type of judicial notice-all these, and more, tend to show that the principal function of the adversary system is to present a controversy to the Court. The litigants are important because only they can activate the judicial process. .

Unlike legislators or executives, the Court must await the commencement of a lawsuit, which of course limits its power to enunciate policy. That power is also limited by the self-restraint of some Justices, who demand that suits be brought by "proper" plaintiffs in cases involving issues considered amenable to judicial treatment. But self-restraint is, as Mr. Justice Stone once remarked, the only restraint upon the Court once a case has been accepted for decision on the merits. ${ }^{57}$ In this respect it differs in some degree from the avowedly political branches of government, the officials of which are the butt of the pressures of politics. ${ }^{58}$ Of course it is true, or at least seems to be true, that while the Justices are not prey to the day-to-day pulls and tugs of the political process, they nevertheless have their radar rather keenly attuned to what might be called "the art of the possible." Sometimes they have misread the social signals, but usually they have been in tune with the philosophy of the times in which they operated. The point, however, is that the chief function of the adversary system is to trigger a judicial response. Sometimes it is difficult for interest groups desirous of a Supreme Court decision to find "proper" plaintiffs; the Negro movement was to some extent characterized by this difficulty, particularly in the early 1950s. However, Americans are a litigious people, and the Court has not lacked business in recent years.

Once the machinery of the adversary system has been invoked, a number of significant shortcomings become evident. In the first place, the growing attention paid to what are given the generic label of "policy considerations" in judicial decision-making clearly

\footnotetext{
${ }^{57}$ United States v. Butler, 297 U.S. 1, 79 (1936) (dissenting opinion). See MAson, Harlan Fiske Stone: Piliar of the LaW 405-18 (1956).

${ }^{8 B}$ Even in the allegedly independent regulatory commissions, policies tend to be the resultant af a parallelogram of conflicting political forces. See BERNSTEIN, REGULATING BUSINESS BY INDEPENDENT COMMission (1955). See also FRIENDLY, THE FedERAL Administrative Agenctes (1962); HoRsky, ThE Washincton LAWYER 59-119 (1952).
} 
evidences a breakaway from the traditional adversary system. ${ }^{50}$ What are "policy considerations?" Often employed but seldom defined, the term is one of the most loosely used in legal terminology. When it is defined it is in terms of higher level abstractions, which become meaningless in application. ${ }^{80}$

However, when policies are identified, and when they stand in opposition to doctrinal commands, a judge must act as legislator, ${ }^{61}$ since weighing considerations of social advantage is what legislatures do, subject to judicial vetoes when constitutional limitations are transgressed. But it is also what courts inevitably do. Policy considerations are part of the legal order, not outside of it and not alien to it. The problem is whether the adversary system of constitutional adjudication is adequate to provide relevvant data and criteria for the satisfactory resolution of policy questions. The answer that we suggest is "no." We further suggest that considerable evidence is available now to indicate a departure from the system as it was known historically and that further institutional changes must be developed if the Court is to remain vital. These latter suggestions derive from an evaluation of both the adequacy of the flow of information to the Court and the competence of the Justices to rule on complex problems of public policy.

The notion that the Supreme Court depends upon the adversaries to furnish it with the data relevant and necessary to decision is an obvious fiction. As Judge Wyzanski has stated:

This tendency of a court to inform itself has increased in recent years following the lead of the Supreme Court of the United States. Not merely in constitutional controversies and in statutory interpretation but also in formulation of judge-made rules of

${ }^{80}$ The function of the adversary system is to disclose for resolution factual disputes within the framework of the declaratory theory of law.

${ }^{\circ 0}$ That judges should more forthrightly face the policy considerations behind a rule of law has long been advocated. See, e.g., Holmes, The Path of the Law, 10 HARv. L. Rev. 457, 467 (1897); Llewellyn, Some Realism About Realism, 44 HARv. L. REv. 1222, 1252-53 (1931). However, definitions (or even descriptions) of "policy" considerations are rare. Professors Lasswell and McDougal bave offered the follow. ing: "Policy norms. These are propositions about how values ought to be distributed, including those to which we have given special mention, like power, respect, knowledge, safety and health, comfort and convenience." Lasswell \& McDougal, Legal Education and Public Policy: Professional Training in the Public Interest, 52 YAle L.J. 203, 241 (1943). (Emphasis in original.)

${ }^{\circ 1}$ The Supreme Court also acts as a legislature when it refuses to act. See Harper \& Rosenthal, What the Supreme Court Did Not Do in the 1949 Term-An Appraisal of Certiorari, 99 U. PA. L. REv. 293 (1950). 
law, the justices have resorted, in footnotes and elsewhere, to references drawn from legislative hearings, studies by executive departments, and scholarly monographs. ${ }^{62}$

The object is to inform the judicial mind, and that is done by adversaries in briefs and oral argument and by the Justices who take cognizance of material deemed relevant and helpful to them. ${ }^{63}$ The policy function which the Court must perform "can only be successfully carried out if the Court consciously strives to inform itself as fully as possible of the factual setting of each case and the social consequences likely to flow from each decision."64 In addition, part of an adequate informing process must be directed at assisting the Justices to select the "correct" criteria for evaluating and, at times, choosing from among several relevant policies. ${ }^{65}$

The problem has troubled some of the Justices, who have not found the orthodox means of informing the judicial mind adequate. Mr. Justice Frankfurter once remarked: "Can we not take judicial notice of writing by people who competently deal with these prob-

${ }^{\circ 2}$ Wyzanski, A Trial Judge's Freedom and Responsibility, 65 Harv. L. Rev. 1281, 1295 (1952). The author continued: "Such resort is sometimes defended as an extension of Mr. Brandeis' technique as counsel for the state in Muller v. Oregon. In Muller's case, however, Mr. Brandeis' object was to demonstrate that there was a body of informed public opinion which supported the reasonableness of the legislative rule of law. But in the cases of which $I$ am speaking these extra-judicial studies are drawn upon to determine what would be a reasonable judicial rule of law. Thus the focus of the inquiry becomes not what judgment is permissible, but what judgment is sound. And here it seems to me that the judge, before deriving any conclusions from any extra-judicial document or information, should lay it before the parties for their criticism." Id. at 1295-96. (Emphasis in original.)

o3 The signals or inputs a judge receives are usually conflicting; in addition, they are normatively ambiguous. In other words, there is difficulty enough with the "is" but when it comes to the "ought," then any decision-maker, including a judge, is beset with a welter of inconsistent demands. Cf. Lasswell \& McDougal, supra note 60, at 239-43. See also ShKLar, LEgalism passim (1964).

or Alfange, The Relevance of Legislative Facts in Constitutional Law, 114 U. PA. L. REv. 637, 639 (1966).

"s See Cohen, The Faith of a Liberal 192-93 (1946): "If, however, there are any principles of political science which enhightened experience makes clear, they are (1) that the worst form of government is that which separates power from responsibility, and (2) that the weakest government is that which has relatively little access to the sources of information. And does not the fiction that the courts only follow the words of the Constitution in fact relieve them of the responsibility . . . and is it not also true that this fiction that the courts decide only questions of law prevents us from organizing the courts so that they could have the opportunity of making adequate investigation into the actual facts on which they have to pass? Do we want our judges to be not only irresponsible to any earthly power, but also independent of adequate knowledge of the social consequences of their decisions?"

For a recent exposition of the use of socio-legal data in adjudication, see Green, Sociology in Court, Wall Street Journal, April 10, 1967, p. 1, col. 1. 
lems? Can I not take judicial notice of Myrdal's book without having him called as a witness? ... It is better to have witnesses, but I did not know that we could not read the works of competent writers." 68 In this same connection, Mr. Justice Brennan has observed that "the briefs of counsel are always helpful, but each of us is better satisfied when he not only checks but also supplements those materials with independent research." ${ }^{\text {it }}$ A serious difficulty with this procedure of self-information which goes to the heart of the judicial system is that the adversaries will have no opportunity to know or to meet such information with opposing or contradictory data. A further trouble is that no guidelines exist by which the Justices are to act; each is free to do as little or as much "independent research" as his time (and that of his assistants) will permit. On the other hand, he is not required to do any at all, and can wholly rely upon what counsel brings to him. He is free to be as lazy or energetic as he wishes.

Moreover, to the extent that "independent research" is conducted, there is a breakaway from the orthodox view of the function of the adversary system. The judge himself becomes an active and avowed element in the informing process. Of course he can do this without violating the expectations of the adversary system by relying upon a liberalized and expanded concept of judicial notice. Information can and does flow to the Supreme Court dehors the "normal" paths. Moreover, the same occurrence may be observed throughout the adjudicatory process, whether it is judicial or administrative. ${ }^{68}$

"Frankfurter, J., quoted from oral argument in MURPHY \& PRITchetr, Courts, JUdGes, AND POLITICS 318 (1961).

${ }^{67}$ Brennan, Working at Justice, in AN Autobrography of THE Supreme Court 299, 303 (Westin ed. 1963).

${ }^{\circ}$ See Wormuth, The Impact of Economic Legislation upon the Supreme Court, 6 J. Pub. L. 296, $307-08$ (1957). See generally 2 Davis, Administrative Law Treatise $\$ \S 15.01-.14$ (1958, Supp. 1965). Put another way, the Supreme Court at times takes "legislative facts" into consideration. See Alfange, supra note 61, at 667-79; Karst, Legislative Facts in Constitutional Litigation, 1960 SUP. CT. REV. 75.

The expanded use of amicus curiae briefs appears to be an outgrowth of the Court's desire to learn more about the law which they are called upon to make. See Krislov, The Amicus Curiae Brief: From Friendship to Advocacy, 72 Yale L.J. 694, 717 (1963). Primary evidence of the use of extra-record facts in constitutional adjudi. cation can be found in Dennis v. United States, 341 U.S. 494 (1952). See also Cascade Natural Gas Corp. v. El Paso Natural Gas. Co., 386 U.S. 129 (1967) (Stewart, J., dis. senting): "[T]he Court lays down 'guidelines' with respect to complex issues which will shape the future of an important segment of this Nation's commerce. In so 
"The adversary principle," Professor Philip Selznick has observed, ". . . lends legitimacy to partisan advocacy within the legal process, allowing and even encouraging the zealous pursuit of special interest by means of self-serving interpretations of law and evidence." constitutional adjudication, however, it is apparent that these selfserving interpretations do not-cannot-carry the weighty task of bringing all of the data and arguments to the attention of the Court. Even the use of amici curiae briefs and of "Brandeis briefs" fall short of the need. Independent research, conducted by "judge and company," apparently is considered necessary. The adversary system is simply not adequate to the need; the parochial and specialized interests of individual litigants, whether natural or corporate persons or unincorporated associations, cannot fully produce all the information which the Justice needs in coming to a decision and in writing his opinion. As Selznick says, the assumptions behind the adversary principle "have not been fully analyzed or tested," and "there is evidence that partisan advocacy is weakened under conditions that may become increasingly prevalent: [including] the commitment of a tribunal to a positive outcome ... [and] reliance on experts and investigators who serve the court directly ...."70 As the Supreme Court in its constitutional decisions becomes more and more purposive or instrumental-that is, pays greater attention to the policy considerations-the need for analysis and testing of the adversary system has become obvious. The Court is drawing away from it, but has not yet produced a viable alternative means of decision-making. The Court is still a court, hampered by all of the shortcomings of litigation as a means of developing public policy.

Litigation-the adversary system-is not adequate, for other reasons as well. In addition to the invalidity of the underlying assumption that the flow of information to the Court is sufficient to

doing the Court roams at large, unconfined by anything so mundane as a factual record developed in adversary proceedings."

oo SELZNICK, SOciologY of LAW 16 (1965) (mimeographed; to be published in the forthcoming International Encyclopedia of Social Sciences) (quoted by permission). Of importance, but of peripheral interest to the inquiry here, is the inadequacy of the adversary system-of judicial review itself-when so-called "low-visibility" administrative decisions are challenged. These small claims are not worth litigating, even though they may be of importance to the individual; accordingly, some other institution, such as the "ombudsman," may well be in order. On this point, see GELLHORN, When Americans Complatn (1966).

${ }^{80}$ Ibid. 
the need, there is another (also unwarranted) assumption of equal or greater importance: that the Justices have the competence or expertise requisite to make many of the pronouncements on public policy that they issue. A final unfounded assumption is that the Justices have some means of forecasting and evaluating the social consequences of their decisions-which, again, is simply not true. These latter two inadequacies of the adversary system may be treated together.

Supreme Court Justices must rise above the narrow knowledge and analysis.presented by the litigants and view the scheme or problem entire. The late Judge Charles Clark said in 1956 that "experience has taught me that only rarely and perhaps fortuitously may an opinion be expected to rise above its sources in the presentations of counsel." 1 One would have to examine all of the data formally presented to the Supreme Court in individual cases to determine whether Judge Clark's assertion is valid for the High Bench. The arguments and information presented often do require the independent research we have mentioned, although that research may be confined (in most, if not all, cases) to the arguments and issues presented by counsel. Professor Lon Fuller has observed that the moral force of a judgment is at a maximum if a judge decides solely on the basis of arguments presented to him. "Because if he goes beyond these he will lack the guidance given him by the parties and may not understand the interests that are affected by a decision rendered outside that framework." 72 But that is often what he must do, for as Woodrow Wilson said, Americans look for "statesmanship" in their judges. ${ }^{73}$

Fuller's statement is helpful so far as it goes, but it fails to take into consideration the growing evidence of the lack of judicial competence or expertise, which is sometimes expressly recognized by members of the Court and sometimes an obvious conclusion from the manner in which opinions are written. ${ }^{74}$ Judges, for example,

\footnotetext{
${ }^{71}$ Harmar Drive-in Theater, Inc. v. Warner Bros. Pictures, Inc., 289 F.2d 555, 559 (2d Cir. 1956) (Clark, J., dissenting).

72 fulier, The Problems of Jurisprudence 707 (1949).

${ }^{78}$ Wilson, Constitutional Government in the UNITEd States 168 (1908).

"7 See, e.g., Railroad Comm'n v. Rowan \& Nichols Oil Co., 310 U.S. 578, 580.82 (1940), and 311 U.S. 570, 575-77 (1941). In administrative law, the point is exemplified in the cases involving the "scope of review" of administrative decisions. See 4 Davis, op. cit. supra note $68, \S \S 29-.01-.11$.
} 
do not receive the type of economic analysis requisite to better decisions. Mr. Justice Frankfurter, in an off-bench statement, made the point in these words:

Take a problem that has been confronting the Supreme Court, Sherman Law regulation of the movie industry. A number of decisions have been rendered finding violations under the Sherman Law. Does anybody know, when we have a case, as we had one the other day, where we can go to find light on what the practical consequences of these decisions have been? ... I don't know to what extent these things can be ascertained. I do know that, to the extent that they may be relevant in deciding cases, they ought not to be left to the blind guessing of myself and others only a little less informed than I am.75

This passage tells us several things: (a) the bench, at least in antitrust cases, has no particular expertise and must be educated; (b) the bar has not been helpful in this educational process; (c) judges are concerned with the consequences of decision as well as doctrine; and (d) the adversary system may be at fault in that it does not provide a court with the proper institutional means of informing itself. Judges have no way of becoming expert on many matters and must make, as Frankfurter suggests, "blind" guesses. Neither can they forecast the societal impact of their decisions, for the system does not provide a way of feeding back that data to them-assuming that it is available, which assuredly it is not. Furthermore, judges are not "renaissance men"; they cannot be expected to be expert in all of the complex problems presented to them.

Paying attention to policy considerations-adhering to a "jurisprudence of consequences"-makes adjudication enormously more complicated. For a judge to weigh considerations of social advantage is far more difficult than to apply rules or announce prin-

${ }^{75}$ Frankfurter, Some Observations on Supreme Court Litigation and Legal Education 17 (1954). See General Bronze Corp. v. Ward Prods. Corp., 262 F. Supp. 936, 937 (N.D.N.Y. 1966) (Foley, J.) : "Justice Frankfurter wrote in Marconi Wireless Telegraph Co. of America v. United States, 320 U.S. 1, 60, . . that it is an old observation that the training of Anglo-American judges ill fits them to discharge the duties cast upon them by patent legislation. Although not a complete novice in patent legislation, the prolonged deliberation I found necessary in this instance-interfered with often by the pressures of the routine court work, the nature of much of this in this federal district being undeferable-brought home the truth of this old observation and the senselessness by federal judges untrained in the patent art to pretend otherwise." (Parallel citations omitted.) 
ciples in given cases. It calls for a quality of expertise in the legal profession that is rare indeed and for which legal education does little to prepare them. Cardozo noted this many years ago: "Some of the errors of courts have their origin in imperfect knowledge of the economic and social consequences of a decision, or of the economic and social needs to which a decision will respond. In the complexities of modern life there is a constantly increasing need for resort by the judges to some fact-finding agency which will substitute exact knowledge of factual conditions for conjecture and impression."76 The need still exists-and has become more pressing as society has become more complex.

This fact, if none other, should be sufficient to forego adherence to the declaratory theory of law despite any possible symbolic value it may possess. To insist that judges act like judges in the Blackstone manner, in other words, is to deprive them of the very means which would make them more efficient and expert. The adversary system is not likely to be improved unless and until there is a general recognition of its shortcomings and of the needs of rational policy-making by an appointed bench. The adversary procedure embodies a conflict theory and assumes that when two parties are at odds on constitutional issues and cannot settle their differences, by some magic (the legal counterpart of the classical economist's "invisible hand") the Court's resolution will inure to the general good. This will be true, however, only if the Justices have the requisite competence, both to dispose of the substantive matter at issue and to predict the consequences of alternative decisions. Robert H. Jackson, when Attorney General, recorded the astonishment of Europeans that American monetary policy could be decided in a private law suit involving \$15.60.77 National public policies cannot (and will not) continue to be made judicially, we suggest, unless some better means of making decisions is created. Of course, it is true that the Court has recognized its limitations in a number of matters (including monetary policy) with the possible result that a further diminution of

${ }^{76}$ Cardozo, The Growth of the Law 116-17 (1924).

77 Jackson, The Struggle for Judicial Supremacy 103 (1941). For a statement that non-adversary procedure is more appropriate in some cases than adversary procèdure, see Hyser v. Reed, 318 F.2d 225, 237-38, 246 \& n.20, cert. denied, 375 U.S. 957 (1963) (parole board procedures). See also Kaplan, Civil Procedure-Reflections on the Comparison of Systems, 9 BuFfalo L. REv. 409 (1960) (comparing German system with American adversary system). 
power in the Supreme Court may take place. In any event, the conclusion seems valid: the adversary system is inadequate.

\section{A Third Proposition}

The final proposition may be stated as follows: If the Supreme Court is to remain a significant and meaningful instrument of governance, then it must react and direct itself to an ever-changing reality. What is needed is that the Supreme Court find itself a new role, as well as new institutional characteristics. When in the late 1930 s and 1940s it abdicated its position as an authoritative faculty of political economy and ceded to the political branches of government ultimate control over politico-economic decisions, the need was evident-and pressing-for the creation of a new role. This was found in the drive for equality-the Negro rights cases, the urban voter cases, the criminal law cases-by Justices deeply concerning themselves with the workings of society and tackling some abrasive problems they (as also the other organs of government) had theretofore avoided. ${ }^{78}$ The spin-off from this activity has been great-in legislation, in executive programs, in state laws. But the very success of the Warren Court-and, outwardly at least, it has been highly successful, perhaps the most successful Court in history-raises two crucial questions: (1) Has the Court about worked itself out of critical social problems with which to deal? ${ }^{79}$ and (2) Why has the Court had this success?

${ }^{78}$ In the drive for racial equality, franchise equality and fair treatment of criminal suspects, for political and other reasons, the Conrt became the only governmental organ that could institute constitutional change. What it did there, as well as elsewhere, was to open the way to change, which has come with breathtaking speed in reapportionment matters but which has been slow indeed with respect to the position of the Negro. In this latter regard a report of the Civil Rights Commission issued in February, 1967, indicated that racial isolation in education is increasing, both in the South and North, despite the Brown decision. See Washington Post, Feb. 20, 1967, p. A-1, col. 8, and p. A-5, col. 1 .

${ }^{70}$ We are aware that merely posing such a question will astonish many students of the Court. What is said subsequently in the text is in terms of long-range tendencies rather than what may (or may not) occur in the near future. In brief, our position is predicated on the belief that the activism of the Warren Court is a short-term phenomenon. In this connection, compare Adderley v. Florida, 385 U.S. 39 (1966), with Fortson v. Morris, 385 U.S. 231 (1966). What is being suggested may be characterized as neither a tactical retreat nor a full-scale strategic withdrawal by the Court; rather, it is that the center of goverumental gravity is slipping ineluctably toward the political branches of government and that the Court at some time will find itself with little of a fundamental nature on its docket.

See Graham, Supreme Court Preview: A Quieter Year Ahead, N.Y. Times, Oct. 2, 1966, p. E-8, col. 1: "The Supreme Court convenes tomorrow for the ceremonial 
So far as basic law is concerned, the voting situation is about settled, the Negro now has equality in law if not in fact, and there is little that can be done by way of developing new principles in the criminal law area. In each of these doctrinal fields, to be sure, cases will continue to be brought to the Court for settlement; but in large part they will result in resolution and refinement of the details of already established principle. ${ }^{80}$ For example, the Court may venture into the areas of juvenile courts ${ }^{82}$ and military law. But that development, if it comes, would merely extend its recent criminal law holdings. What may be foreseen, then, is a diminishing role for the Court-unless and until new areas are tackled. Furthermore, it is difficult indeed to discern what these areas might be. Our suggestion is that the Court will soon have to start a search for a new role, or find itself increasingly concerned with the minutiae of public policy.

It is here that the second question obtrudes: Why has the Court been successful in recent years? This success is taken for granted, applauded or disapproved in accordance with the observer's personal values, with little or no effort made to learn the bases for it. It is suggested, inter alia, that the Court has succeeded because it has,

opening of its 1966 term, amid indications that the pendulum is swinging back from the high point of its liberalizing impact on American life.

"The shift results not from changes of mind or personnel on the Court, but rather through the steady shrinking of the number of the nation's ills that take the form of unjust laws. ... $[A]$ review of the Court's upcoming work suggests that fewer of the nation's major problems are coming its way."

${ }^{80}$ The success of the Warren Court in promulgating national norms in the areas of civil rights and civil liberties should not be taken to mean that these norms have been or will be translated into operational reality. The contrary may well be the case. Cf. Miller, Mulkey v. Reitman: A Brave But Futile Gesture?, 14 U.C.L.A.L. REv. 51 (1966); Miller, On the Need for "Impact Analysis" of Supreme Court Decisions, 53 GEo. L.J. 365, 389-92 (1965); Wells \& Grossman, The Concept of Judicial PolicyMaking: A Critique, 15 J. PUB. L. 286 (1966). The power of the Court to change the behavior patterns of Americans is at best unknown and highly discontinuous. Despite all the Court has done in recent years in rendering decisions having the projected effect of enhancing the dignity of disadvantaged Americans, its history as a protector of the unlettered and weak and of dissenting minorities has been anything but favorable.

Furthermore, with a change in Court personnel, which will come soon, it is possible that the thrust and tenor of recent decisions will be reversed. In addition to Mr. Justice Tom C. Clark, who has already announced lis retirement to take place in 1967, there may be two or three other vacancies within the next year or two. A shift in position is even possible in some areas without a change in personnel, as the Court reads the social tea leaves and perceives the white reaction to what some consider to be excesses in the Negro movement and the growing involvement in a war in Asia.

${ }^{81}$ See Paulsen, Kent v. United States: The Constitutional Context for Juvenile Cases, 1966 Sup. Cr. REv. 167. 
as Alexander Pekelis suggested twenty years ago, immersed itself in the travail of society. ${ }^{82}$ Since 1940 it has made itself meaningful to the drives and urges of significant segments of the American people and has been able to translate into constitutional command some of the ideals of the Constitution which have long lain dormant. The Justices have recognized that it makes little sense in a unified, if not entirely uniform, nation for the principle of Barron v. Baltimore $e^{83}$ still to apply. Furthermore, and probably of vastly greater importance, they did not hesitate to grasp the nettle of racial segregation at the very time that the Congress was moribund, the Executive reluctant, and the Negro people on the march; and they recognized that "one malarious peasant" should not be permitted to wield electoral power equal to that of twelve residents of a city. In so doing, they have made themselves part of a government of affirmative orientation, part, that is, of the Positive State. ${ }^{84}$ They have been creating a teleological jurisprudence in harmony with the politico-economic decisions of Congress and the Executive.

In making these advances, the Court does not appear to have markedly or obviously diminished in public esteem. Efforts to reverse the Court's reforms have aborted. In addition, Senator Sam Ervin of North Carolina is, at this writing, striving to have a bill enacted which would enlarge the Court's powers. ${ }^{85}$ By its decisions the Court has remained meaningful to the American people and its continued acceptance will not depend upon its adherence to the declaratory theory or whether its decisions are "reasoned" or "principled"-unless the terms "reason" and "principle" are taken to mean, not logical derivations from pre-existing doctrine, but " $a$ process of disciplined observation, coupled with a recognition that

8a See note 45 supra and accompanying text. See Miller, Notes on the Concept of the "Living" Constitution, 31 GEO. WASH. L. REv. 881, 911 (1963).

ss 32 U.S. (7 Pet.) 243, 250 (1833) (announcing that the Bill of Rights applies only to the federal government).

84 The concept of the Positive State is developed in previous articles by the senior author. See Miller, The Public Interest Undefined, 10 J. PuB. L. 184 (196I); Miller, An Affirmative Thrust to Due Process of Law?, 30 GEO. WASH. L. REv. 399 (1962); Miller, Constitutional Revolution Consolidated: The Rise of the Positive State, 35 GEO. WASH. L. REv. 172 (1966).

${ }^{85}$ S. 2097, 89th Cong., 1st Sess. (1965). See Hearings Before the Subcommittee on Constitutional Rights of the Senate Committee on the Judiciary, 89th Cong., 2d Sess., pts. 1, 2 (1966). The bill would confer standing to challenge expenditures to sectarian institutions under certain federal aid-to-education statutes. 
choices must be made among alternatives and a cognizance of the consequences of the decisions. ...."88

At present, three areas seem possibly ripe for greater judicial development, with the result that the Supreme Court might maintain its position of power and respect. While other areas might be suggested, Court activity to provide greater review of public administration, clearer recognition of the group basis of society, and adaptation of a domestically oriented Constitution to an interdependent world would be especially propitious. The passport cases, the criminal law cases, and some recent administrative law decisions all point to a greater interest in the individual qua individual in his dealings with the public administration. So, too, with the group basis of society, although the Court has been reluctant overtly to recognize it. However, a number of cases at least give a hint of the development toward a constitutional theory of group action. ${ }^{87}$ Furthermore, there is the decision in Marsh $v$. Alabama ${ }^{88}$ existing in the United States Reports as a time bomb ticking away, available for use whenever the Court would desire to recognize the governmental character of the huge corporate combines. ${ }^{89}$ While there is some indication that the Court will consider the third area of possible activity, the reluctance to rule in the area of foreign affairs may minimize such a venture..$^{90}$ The extent to which the Supreme Court can successfully assimilate such constitutional tasks cannot, of course, be forecast with precision. At a time when the docket each year is crowded and when students of the Supreme Court are calling upon the Justices to make fewer decisions, it may seem odd to suggest that

${ }^{80}$ Miller \& Howell, The Myth of Neutrality in Constitutional Adjudication, $27 \mathrm{U}$. CH1. L. REV. 661, 694 (1960). Another view may be found in Bickel, ThE LEAST Dangerous Branch (1962). See Wechsler, Toward Neutral Principles of Constitutional Law, 73 HaRv. L. REv. 1 (1959).

${ }^{87}$ See Horn, Groups and the Constitution 152.180 (1956); Miller, Private GOVERNMENTS AND THE CONSTITUTION 13 (1959).

Bs 326 U.S. 501, 507 (1946). See Berle, Constitutional Limitations on Corporate Activity, 100 U. PA. L. REV. 933, 949-51 (1952).

${ }^{8}$ See PeKelis, Private Governments and the Federal Constitution, in LAw AND Socral Acmon 91 (Konvitz ed. 1950).

${ }^{\circ 0}$ See Banco Nacional de Cuba v. Sabbatino, 376 U.S. 398 (1964); Moore, Federalism and Foreign Relations, 1965 Duke L.J. 248. Subsequent to the decision, Congress enacted a statute which will require a Court decision on the merits of the case. Foreign Assistance Act of 1964, 78 Stat. 1013, 22 U.S.C. $\$ 2370$ (e) (2) (1964). The statute, upheld in the district court, Banco Nacional de Cuba v. Farr, 243 F. Supp. 957 (S.D.N.Y. 1965), 6 VA. J. INT'L L. 173 (1965), has not yet reached the Supreme Court. See also F. Palacio y Compania v. Brush, 256 F. Supp. 481 (S.D.N.Y. 1966). 
the time is fast approaching when a new constitutional role for the High Bench must be carved out. But precisely that is suggested.

Whether the three areas of possible concern will in fact be tackled is not at all certain. Without the institutional means necessary to make "rational" decisions in a nation increasingly dominated by "technocrats," it may well be that none of the areas-nor, for that matter, others that might be mentioned-will receive serious concern. That the social milieu in which the Court operates is ever changing is an obvious truism-but one not sufficiently faced as yet. ${ }^{91}$ Dean Don $\mathrm{K}$. Price, in a seminal book, ${ }^{92}$ attributes the factor of change, both in extent and in its rapidity, to the scientific revolution. ${ }^{93}$ Science (and its by-product, technology) are creating situations which pose fundamental problems to the nature of American democracy. ${ }^{94}$ Public policies in the future, according to Dean Price, will be determined more by scientific and technological developments we cannot now foresee than by political (or legal) doctrines that we can now state. ${ }^{95}$ The conditions of human existence have been altered more in the past one hundred years than in all of previous human history and the future portends even faster change. ${ }^{96}$ Already government has undergone radical alterations from that condition which existed as recently as 1900 . The age of administration, of bureaucracy, of planning has come; organizations dominate the polity; the lines between public and private and between foreign and domestic are being blurred.97 Legislatures and courts are nineteenth century institutions, neither of which has demonstrated any high degree of interest or ability in improving its methods to meet new conditions.

02 Cf. Miller, Technology, Social Change, and the Constitution, 33 Geo. Wash. L. REV. 17, 19-20 (1964).

os Price, The Scientific Estate (1965), reviewed in Miller, Book Review, 1966 DUKE L.J. 622.

${ }^{\circ 8}$ Id. at $15-20$.

on The scientific revolution is one of the vital forces "behind institutions, behind constitutional form and modifications" which historian Frederick Jackson Turner maintained called "these organs into life and shaped them to meet changing conditions." TuRner, TrEe FrontIER IN AMERICAN History 2 (1920). See Landynski, The Making of Constitutional Law, 31 Soctar Research 23 (1964).

os PrICE, op. cit. supra note 89 , at 186.

See ibid.; Commoner, Science and Survivat (1966); LAPP, The New Priesthood (1965).

${ }^{97}$ Adumbrated in Miller, Constitutional Revolution Consolidated: The Rise of the Positive State, 35 GEo. WASH. L. REv. 172, 182-84 (1966). 
The three areas of possible judicial interest mentioned above all involve, in greater or lesser degree, aspects of the scientifictechnological revolution. One may speak normatively and say that the Supreme Court should not shy from the issues presented by them. But we are not hopeful. That is a dour note on which to end this commentary about the power of the Court; nevertheless, it does seem to be justified. To make a prediction: the "activist" Court presided over by Chief Justice Earl Warren will soon taper off into relative desuetude.

\section{By WAY OF CONCLUSION}

The hypotheses suggested in this article are not to be considered as anything more than tentative formulations. If empirically validated, they would go far toward showing that the symbolic view of the Court and of the orthodox notion of the rule of law are not requirements of a viable legal order. The point we should like to emphasize, however, is not that Professor Mishkin's analysis and conclusions are shaky. Rather it is that further intuiting of conclusions about the Supreme Court, usually based upon nothing more than casuistical exercises on Court opinions, will not serve the needs of scholarship or, of far greater importance, of that greater understanding of adjudication which will at once permit higher levels of attainment by bench and bar and result in maintenance of the Court's position in the power structure of American government.

As matters stand now, we suggest, the Court is on the verge of a considerable diminution of power vis-à-vis the avowedly political branches of government. That would be a tragedy, for it seems clear beyond peradventure that the High Bench, if it seizes the opportunities, could have a role, however immeasurable, to play in helping effect the nexus between a proliferating government and the individual on the one hand and between the pluralistic centers of power in American society and the individual (and also as between those centers of power and government) on the other.

The Court will not be able to accomplish these objectives unless and until is it institutionally buttressed. If law, as Frankfurter said, "presupposes sociological wisdom as well as logical unfolding,"98 the Court must have the assistance necessary to make sociologically wise

${ }^{98}$ Frankfurter, The Process of Judging in Constitutional Cases, in AN AUTo. BIOGRAPHY OF THE SUPREME COURT 267, 270 (Westin ed. 1963). 
decisions in a dynamic social milieu. On this score, one should not be at all optimistic, for the likelihood is that little meaningful will be done. Perhaps incremental improvements will come about, possibly through expanded use of amici curiae briefs but more probably only as individual Justices perceive and act upon the need. But that will not suffice. Just as it has become evident in recent years that Congress must reorganize itself if it is to retain its present power, attenuated though it may be, ${ }^{99}$ so too the Supreme Court and commentators must recognize that the adversary systemthe product of private-law litigation in an agricultural, even feudal society-and the declaratory theory are simply not adequate in the modern era. What type of improvements or changes should be made we only partially suggest. However, just as there is a vital need for factual studies of the legal order, ${ }^{100}$ including constitutional adjudication, a concomitant requirement exists for the invention of new techniques and new aids for the nine men whose fate it is to sit upon the Supreme Court of the United States. The American people by and large do seem still to be willing to permit the Court to make its ostensibly portentous pronouncements upon public policy, and thus to wield some political power. How long this will continue we do not predict.

The new constitutional order which has become so familiar in recent years, following the watershed year of 1937, has produced a government of affirmative responsibility-the Positive State. Exemplified in many legislative and administrative programs, it is the American version of the welfare state. During this period the Supreme Court, without announcement and without fanfare but with considerable controversy, has been engaged in working out an affirmative set of constitutional concepts. ${ }^{101}$ The Positive State requires such a positive jurisprudence. If, as Woodrow Wilson said, "constitutions must be Darwinian in structure and practice," so too must the institutions of government. The Supreme Court must be ready and able to meet the challenges of the unknown future.

\footnotetext{
${ }^{\circ 0}$ See, e.g., The CONGress AND America's Future (Truman ed. 1965).

${ }^{100}$ See, e.g., Schubert (ed.), Judicial Behavior 4 (1964); Kommers, Professor Kurland, the Supreme Court, and Political Science, 15 J. PUB. L. 230 (1966), ${ }^{101}$ Cf. Rostow, The Sovereign 'Prerogative (1962).
} 